8. Mineev, V. \& Lebedeva, L. (2003). Istoriya agrokhimii $i$ metodologii agrokhimicheskikh issledovaniy: ucheb. posobie [The history of agrochemistry and methodology of agrochemical research: textbook. allowance]. Moskva: MGU [in Russian].

9. Orlovskyi, M. \& Kuzmych, S. (1967). Do 125-richchya z dnya narodzhennya A. Ye. Zaykevycha [On the 125th anniversary of the birth of A. E. Zaikevich]. Visnyk sil's'kohospodars'koyi nauky - Bulletin of Agricultural Science, 12, 15-117 [in Ukrainian].

10. Pavlovskiy, I. (1912). Kratkiy biograficheskiy slovar' uchenykh i pisateley Poltavskoy gubernii s poloviny XVIII veka [A brief biographical dictionary of scientists and writers of the Poltava province from the half of the eighteenth century]. Poltava [in Russian].

Одержано 10.05.2019.

УДК 613:070 (477) «185/192»

\author{
Коцур Надія, \\ доктор історичних наук, професор, \\ завідувач кафедри медико-біологічних \\ дисциплін і валеології, \\ n.kozur@ukr.net \\ https://orcid.org/0000-0003-4720-2227 \\ Researcher ID: W - 4065 - 2018 \\ Державний вищий навчальний заклад \\ «Переяслав-Хмельницький державний \\ педагогічний університет імені Григорія \\ Сковороди», \\ вул. Сухомлинського, 30, \\ м. Переяслав-Хмельницький, \\ Київська обл., Україна, 08401
}

\section{DOI https://doi.org/10.31470/2415-3567- 2019-46-136-146}

\author{
Kotsur Nadia, \\ Doctor of Historical Sciences, \\ professor, Head of Department of Medical and \\ Biological Disciplines and Valeology \\ n.kozur@ukr.net \\ https://orcid.org/0000-0003-4720-2227 \\ Researcher ID: W - 4065 - 2018 \\ Pereiaslav-Khmelnytskyi Hryhorii Skovoroda \\ State Pedagogical University, \\ 30, Sukhomlynsky Str., \\ Pereiaslav-Khmelnytskyi, \\ Kyiv region, Ukraine, 08401
}

\title{
ФОРМУВАННЯ І ПОШИРЕННЯ СОЦАЛЬНО-МЕДИЧНИХ ІДЕЙ В УКРАЇНІ НА СТОРІНКАХ ПЕРІОДИЧНИХ ВИДАНЬ (ДРУГА ПОЛОВИНА ХІХ - 20-і рp. ХХ ст.)
}

У статті висвітлюються питання формування $i$ поширення соиіально-медичних ідей в Україні на сторінках періодичних медичних видань другої половини XIX - 20-х рр. $X X \mathrm{~cm}$. У прочесі виконання дослідження застосовано методи джерелознавчого та термінологічного аналізу.

3'ясовано, що медична періодика відігравала вагому роль у формуванні і поширенні медичних знань, значенні наукових відкриттів для практичної медицини, наданні пріоритету профілактичній медицині, популяризачії наукової медицини, переконанні своєчасності звернення населення за медичною допомогою тощо. Спеціальна медична преса в другій половині XIX - початку XX століть посіла чільне місие в системі соціальної комунікації. У 9 губерніях Наддніпрянської України виходило друком 186 спеціалізованих періодичних і продовжуваних видань із питань гуманітарної медицини, які $\epsilon$ иінним джерелом історії становлення та розвитку соиіальної медицини. Санітарні лікарі земств ділилися досвідом щзодо розбудови санітарної справи на сторінках журналів «Архив судебной медищины и общественной гигиены» (1865 - 1871), «Вестник судебной медицинь 
и общественной гигиены» (1885 - 1889), «Вестник общественной гигиены, судебной и практической медициныл (1889 - 1917) та ін.

Встановлено, щзо лікарсько-санітарні хроніки та інші земські періодичні видання містили багатий матеріал про захворюваність і смертність населення України, про стан медичної допомоги, пропагували здоровий спосіб життя. На сторінках журналів приділялася значна увага питанням народного здоров'я та громадської медииини, публікувалася велика кількість статей з різних питань суспільної гігієни, організації земської медицини, боротьби з соціальними та інфекційними хворобами, санітарноосвітньої роботи серед населення.

Ключові слова: періодичні медичні видання, соціальна медицина, земський лікар, суспільна гігієна, епідеміологія, вчені-гігієністи, журнал, профілактика.

\section{FORMATION AND DISTRIBUTION OF SOCIO-MEDICAL IDEAS IN UKRAINE ON THE PAGES OF PERIODIC ISSUES (SECOND HALF OF THE $19^{\text {th }}-20$ ies of the $20^{\text {th }}$ )}

The article deals with the issues of the formation and dissemination of social and medical ideas in Ukraine on the pages of periodicals in the second half of the 19th - 20ies of the 20th century. In the course of the study, the methods of source and terminological analysis were applied.

It has been found out that medical periodicals played a significant role in the formation and dissemination of medical knowledge, the importance of scientific discoveries for practical medicine, giving priority to preventive medicine, promoting scientific medicine, convincing the timeliness of the public's appeal for medical assistance, etc. Special medical press in the second half of $19^{\text {th }}$ - early $20^{\text {th }}$ took a prominent place in the system of social communication. In 9 provinces of Dnieper Ukraine, 186 specialized periodicals and continuing publications on humanitarian medicine were published, which are a valuable source of the history of the formation and development of social medicine. County Sanitary Doctors shared their experience in building a sanitary case on the pages of the magazines "Archive of Forensic Medicine and Public Hygiene» (1865 - 1871), "Bulletin of Forensic Medicine and Public Hygiene» (1885 1889), "Bulletin of Public Hygiene, Forensic and Practical Medicine» (1889 - 1917), and others.

It has been established that medical chronicles and other county periodicals contained rich material on the morbidity and mortality of the population of Ukraine, on the state of medical care, and promoted healthy lifestyles. The pages of magazines paid considerable attention to the issues of public health and public medicine, published a large number of articles on various issues of public hygiene, organization of county medicine, fight against social, and infectious diseases, health and educational work among the population.

Key words: medical periodicals, social medicine, county doctor, public hygiene, epidemiology, hygienists, journal, prevention.

Медична періодична преса завжди була джерелом інформації про медичні знання, засобом ознайомлення лікарів $з$ новими методами профілактики, діагностики і лікування хвороб. Як і громадсько-політична періодика, але на вищому кваліфікаційному рівні вона інформувала читачів про стан здоров'я населення, його залежність від умов життя та інших соціальних і біологічних чинників, висвітлювала діяльність закладів охорони здоров'я, досягнення i недоліки у стані медичної допомоги. Періодичні медичні видання поширювали санітарну просвіту серед широких мас населення, друкували поради про збереження і зміцнення здоров'я людей. Їх роль у формуванні і поширенні соціальномедичних ідей має вагоме значення.

Наукові праці учених-гігієністів другої половини XIX - початку XX ст., які друкувалися в періодичних медичних виданнях, слугують розв'язанню актуальних 
проблем сучасності - профілактичній медицині, основні завдання якої спрямовані на попередження соціальних та інфекційних захворювань, формування здорового способу життя.

Особливо вагому роль відіграють періодичні медичні видання в умовах реформування охорони здоров'я в Україні, оскільки метою їх є поширення соціальномедичних ідей, пропагування європейських стандартів соціальної медицини та здорового способу життя. Актуальними сьогодні $\epsilon$ висловлювання відомого вченого-анатома, професора Київського університету імені св. Володимира О.П. Вальтера, проголошене ще в 1860 р.: «За допомогою гласності й безкорисного друкованого слова відшуковуються шляхи для покращення нашого побуту; піднімаються питання, які підтримує вся освічена публіка; в усіх сферах державного побуту й адміністрування помітне прагнення до реформ шляхом критики, логіки та публічності. Чується загальний голос про освічення мас і про участь їх у русі європейської ідеї...Хіба це не час відродження!.. Але це відродження повинне розпочатись із гласності. ... Лікарське співтовариство має право вимагати від гласності захисту ще двох скарбів: захист сучасної науки й захист честі співтовариства» $[6$, c.17].

Як джерельна база дослідження, спеціальна медична преса відігравала вагому роль у формуванні і поширенні медичних знань, значенні наукових відкриттів для практичної медицини, наданні пріоритету профілактичній медицині, популяризації наукової медицини, переконанні своєчасності звернення населення за медичною допомогою тощо.

Серед публікацій, присвячених зазначеній науковій проблематиці, слід відмітити наукові розвідки учених у галузі соціальної медицини, історії України, історії науки й техніки, журналістики. Особливо вагому значимість у висвітленні окремих аспектів соціально-медичної тематики у періодичних медичних виданнях мають публікації М.М. Левіта та М.П. Мультановського [4], В. Плюща [7; 8], О.А. П'ятака [10], I.Ю. Робака [11], В.А. Садівничого [12; 13], О.М. Ціборовського [18; 19] та ін. Більш повний і об'єктивний аналіз періодичних видань про поширення соціально-медичних ідей в Україні проведено в публікаціях Н.I. Коцур [2; 3]. Водночас у літературних джерелах обмаль праць, присвячених грунтовному аналізу соціально-медичної тематики у другій половині XIX - початку XX ст. на сторінках періодичних медичних видань.

Таким чином, аналіз та узагальнення сучасних історіографічних праць зумовило мету написання статmі - історико-науковий аналіз процесу формування і поширення соціально-медичних ідей на теренах України в другій половині XIX - 20-х pp. XX ст. на сторінках спеціальних медичних видань через призму персонологічних та соціокультурних вимірів.

Методологічну базу дослідження склали загальнонаукові методи (методи теоретичного дослідження: аналіз, синтез, класифікація). Особливу увагу приділено власне історичним методам наукового пізнання (проблемно-хронологічному, порівняльноісторичному, ретроспективному). У процесі виконання дослідження застосовано методи джерелознавчого та термінологічного аналізу.

Хронологічні межі дослідження пов'язані $з$ передумовами формування наукових основ соціальної медицини у другій половині XIX ст. земськими лікарями в українських губерніях Російської імперії та виокремленням соціальної гігієни як окремого напряму гігієнічної науки і самостійної навчальної дисципліни в 20-х рр. ХХ ст.

Українські лікарі і вчені, які відігравали провідну роль в медицині Російської імперії, брали також активну участь у виданні спеціальної медичної преси, яка в другій половині XIX початку XX ст. посіла чільне місце в системі соціальної комунікації. Як зазначає дослідник В.А. Садівничий, у період 1860-1920 pp. у 9 губерніях Наддніпрянської України (Волинській, Катеринославській, Київській, Подільській, Полтавській, Таврійській, Харківській, Херсонській та Чернігівській) виходило друком 186 спеціалізованих періодичних $\mathrm{i}$ продовжуваних видань із питань гуманітарної та ветеринарної медицини. Автор поділяє їх за обсягом на газети (4-16 с.), а також «тонкі» 
(20-144 с.) і «товсті» (160-528 с.) видання журнальної та книжко-вої форм. До «тонких» видань журнальної форми відносить власне журнали, а також «Бюллетни...», «Ведомости...», «Обзоры...», «Сведения...», «Хроники...». Обсяг цих видань коливався у межах 36-98 сторінок. До «товстих», найзначніших за обсягом, відносить щорічники, особливо «Труды...» i «Протоколы...» медичних товариств, а також «Записки...» i «Хроники...». Обсяги їх могли досягати 914 сторінок. Однак у основі своїй обсяги «товстих» видань варіювалися в межах 116-256 сторінок. Показовим у цьому плані дослідник вважає «Труды Общества киевских врачей с приложением протоколов», що виходили 2-4 рази на рік упродовж 1894-1913 рр. У 1862/63-1891/92 рр. видання виходило під назвою «Протоколы заседаний общества киевских врачей»; за 1901-1911, 1913 рр. «Протоколы...» Товариства друкувалися у складі «Трудов...», за 1912-1914 pр. у «Врачебной газете» [13, с.12].

За підрахунками В.А. Садівничого, переважна більшість періодичних видань була журнального типу. Зокрема, в Києві впродовж другої половини XIX - початку XX ст. виходили друком 54 видання, в Одесі - 36, у Харкові - 35. Загалом така преса зафіксована у 22 містах і містечках [12, с.377].

Вагомою подією для медичної громадськості Російської імперії став вихід першого в Україні щотижневого наукового медичного часопису «Современная медицина», заснованого професором Київського університету св. Володимира О.П. Вальтером у 1860 р. [8, с.150]. Він виходив до 1880 р. (з 1876 р. у Варшаві) і відзначався високим науковим рівнем, що дозволило відомому історику медицини М.П. Мультановському оцінити його як «одне 3 кращих медичних видань того часу» [7, с.161].

Слід відзначити, що Олександр Петрович Вальтер (1817-1889) був видатним представником наукової медицини того часу. Він у 1841 р. закінчив медичний факультет Дерптського університету, де був учнем М.I. Пирогова. Уже в 1843 р. О.П. Вальтер був призначений ад'юнктом Київського університету, а у 1845 р. захистив дисертацію на ступінь доктора медицини. У 1846 р. він був обраний професором анатомії, фізіології та мікроскопії медичного факультету, де, крім анатомії, читав курси фізіології, хірургії та історії медицини, а також займався лікарською практикою як хірург [18, с. 114]. Окрім наукової і практичної діяльності, О.П. Вальтер приділяв велику увагу пропаганді досягнень сучасної медицини, вважаючи найкращою формою для цього видання періодичного медичного журналу, тематика якого була широкою, а рівень - дуже високим. Сам О.П. Вальтер публікував у ньому статті 3 анатомії, фізіології, гігієни, хірургії, про стан медичної освіти і медичної допомоги в Україні. У цьому часописі друкувалися також відомі київські професори - В.Т. Покровський, Л.А. Марковський, В.А. Субботін, О.Д. Орлов, В.Л. Горецький, Є.І. Афанасьєв та ін. [2, c.410].

Одним з перших медичних часописів, що виходили на теренах Російської імперії, був i «Медицинский вестник», який видавався у Феодосії (Крим) з 1862 до 1886 р. [7]. На сторінках часопису висвітлювалися актуальні питання земської медицини та громадської гігієни.

3 розвитком медичної науки у другій половині XIX - початку XX ст. потреба в поширенні медичних знань значно зросла, що сприяло збільшенню медичних періодичних видань. Якщо в першій половині XIX ст. переважали загальномедичні журнали, то в другій половині XIX - початку XX ст. поширилося видання часописів 3 окремих медичних дисциплін [8].

Особливо вагоме місце приділялося в періодичних медичних виданнях соціальномедичній тематиці. Тому зупинимося на тих періодичних виданнях, які насамперед стосуються соціальної медицини і охорони здоров'я, а також на багатопрофільних виданнях, які висвітлювали ці проблеми. Водночас, надаючи перевагу журналам, що видавалися в Україні, звертатимемо увагу також на часописи, що видавались в тогочасних столицях держави - Петербурзі і Москві, оскільки українські науковці та лікарі часто друкували там свої праці. 
Важливу роль у формуванні гігієни як науки і обгрунтуванні ії громадського характеру відіграв журнал «Архів судової медицини та громадської гігієни», який видався у Петербурзі з 1865 до 1871 р. чотири рази на рік. У ньому вміщувалися статті й замітки, що торкалися проблем медичної поліції, медичної географії, медичної статистики, епідеміології, загальної та соціальної гігієни [18].

На початкового етапі заснування «Архів» був задуманий як офіційне видання Медичного департаменту. Перші два номери за 1865 р. вийшли під редакцією I.В. Бертензона. Третій і наступний номери журналу очолив С.П. Ловцов. 3 цього періоду «Архів» стає органом обміну думками і досвідом земських лікарів з актуальних на той час питань суспільної гігієни. За 6 років його існування було вміщено велику кількість статей 3 різних питань суспільного гігієни, санітарної статистики, комунальної та шкільної гігієни, організації земської медицини, боротьби з дитячою смертністю, сифілісом, алкоголізмом і т. д. На сторінках журналу друкувалися також найважливіші наукові розвідки вчених-гігієністів із Західної Свропи [3, с. 94].

Починаючи із 4-го номера «Архіву» за 1865 р., спеціальним V розділом журналу почали видаватися «Матеріали для епідеміології». Це був інформаційний і програмний матеріал, присвячений питанням боротьби з епідеміями в Російській імперії. Більшість статей публікувалася провінційними земськими лікарями.

Видаючи «Матеріали для епідеміології», С.П. Ловцов ставив завдання щодо об'єднання і спрямування всіх практичних лікарів на боротьбу з епідеміями. У зв'язку з цим у «Матеріалах для епідеміології» був поміщений матеріал, що висвітлював питання створення епідеміологічного товариства і проекту статуту цього товариства. Друкувалася також детальна інформація про міжнародну санітарну конференцію в Константинополі, присвячену питанням боротьби з епідемією холери. Були вміщені статті про хід холери в Одесі та боротьби з нею (Н.О. Бернштейн), про поширення віспяної епідемії в Харківській губернії - інспектора лікарської управи (Я.М. Горбаньов), про причини появи i поширення сибірської виразки в Росії в 1864 р. та ін. [3, с. 95]. Вагоме значення для характеристики епідеміологічних поглядів того часу выдыгравали статті Г.І. Архангельського, який проаналізував і опрацював великий фактичний матеріал, що збирався в Медичному департаменті [9, с. 4].

У міру подальшого накопичення матеріалів виникла необхідність більш оперативного спостереження за ходом розвитку епідемічних хвороб та інформування земських лікарів про епідемічний стан країни. У зв'язку з цим, одночасно з «Матеріалами для епідеміології», в яких продовжували друкуватися наукові та програмні статті, 31 січня 1870 р. почав виходити «Епідеміологічний листок». У цьому виданні містилися відомості про епідемічні і заразні хвороби, які надходили в Медичному департамент із різних лікарських установ - лікарень, військових госпіталів, клінік, медичних товариств тощо [3, с. 95]. Особливу увагу редакція журналу звертала на екстренні повідомлення лікарів про перші випадки захворювання i детальне висвітлення причин поширення епідемій.

Водночас із припиненням видання «Архіву» в 1872 р., перестав виходити i «Епідеміологічний листок». За період існування «Епідеміологічного листка» було надруковано велику кількість цікавих матеріалів, цінних не лише для висвітлення епідеміологічного стану Російської імперії на рубежі $60-70-\mathrm{x}$ рр. XIX ст., але й для характеристики суспільно-медичної думки лікарської інтелігенції того часу. Зокрема, в «Епідеміологічні листку» брав активну участь С.П. Боткін, який присвятив дві статті (у № 3 за 1870 р. і в № 4 за 1871 р.) темі епідемії холери [2, с.112].

Таким чином, вагоме значення «Архіву» полягало в тому, що він сформував профілактичний напрямок демократичної суспільно-медичної думки. Соціально-гігієнічні статті, які друкувалися на його сторінках, торкалися актуальних питань гігієни, санітарії і епідеміології та завоювали йому широке коло читачів, а не лише лікарів. Про його 
наукову і практичну значимість та широку популярність було зазначено в журналі «Дело» (№ 10 за 1868 р.).

Здійснюючи практичну діяльність в губерніях, санітарні лікарі земств ділилися досвідом щодо розбудови санітарної справи на сторінках журналів «Архив судебной медицины и общественной гигиены» $(1865$ - 1871), «Сборник сочинений по судебной медицине, судебной психиатрии, медицинской полиции, общественной гигиене, зпидемиологии, медицинской географии и медицинской статистике» (1872 - 1885), «Вестник судебной медицины и общественной гигиены» (1885 - 1889), «Вестник общественной гигиены, судебной и практической медицины» $(1889$ - 1917) [2, с. 122]. За висловлюванням вченого-гігієніста П.О. Осипова, ці видання були спеціальними літературними органами санітарної справи в Російській імперії. Адже саме вони сприяли формуванню профілактичного напрямку земської медицини та впливали на подальший ії розвиток [5].

До видань, що подавали значний обсяг інформації про демографічну ситуацію та захворюваність населення, мережу медичних закладів, їх фінансування та кадрове забезпечення, підготовку медичних кадрів, медичні товариства тощо, належали щорічні «Отчеты о состоянии народного здравия и организации врачебной помощи в России», які видавались Управлінням головного лікарського інспектора Міністерства внутрішніх справ. Ця інформація давала змогу порівнювати та аналізувати стан здоров'я населення і діяльність закладів охорони здоров'я в різних регіонах країни.

3 розвитком земської медицини у Петербурзі з 1885 до 1888 р. виходить тижневик «Земская медицина», присвячений всім питанням земської медицини, народної гігієни, побуту земських лікарів і діяльності земств щодо народного здоров'я, а у Полтаві впродовж 1888-1894 рр. виходило аналогічне видання «Земский врач» [7].

3 появою і зміцненням санітарних організацій губернських і повітових земств починають виходити майже в усіх губерніях України «Врачебно-санитарные хроники». На сторінках цього журналу земські санітарні лікарі ділилися досвідом профілактичної роботи в губерніях та популяризовували гігієнічні знання. Журнали-бюлетні такого типу видавався у 6 із 8 українських губерній: Катеринославській, Київській, Чернігівській, Подільській, Таврійській i Херсонській. Зокрема, «Врачебно-санитарная хроника Черниговской губернии» (1889-1893, 1916-1917), «Врачебная хроника Херсонской губернии» (18921915), «Врачебно-санитарная хроника Таврической губернии» (1893-1895, 1911 - 1916) i «Врачебно-санитарная хроника г. Симферополя» (1909-1914), «Врачебная хроника Харьковской губернии» (1898-1915), «Врачебно-санитарная хроника Екатеринославской губернии» (1898-1917), «Врачебно-санитарная хроника Киевской губернии (19071915 рр.), та ін. На сторінках зазначених видань друкувалися різноаспектні питання гігієни, епідеміології, санітарної статистики, демографії тощо [17; 18].

Під час першої світової війни у Києві виходили «Врачебно-санитарные известия Управлення главноуполномоченного Российского обшества Красного Креста при армиях Юго-Западного фронта» (1916-1917). В Одесі у 1894 р. видавався «Журнал медицины и гигиены», у Харкові в 1906-1917 pp. - «Харьковский медицинский журнал», в 19061907 pр. - «Вопросы оздоровлення г. Харькова и обзор деятельности городской врачебносанитарной организации». В Одесі у 1892-1896 рр. друкувалась «Южно-русская медицинская газета». 31895 р. видавалися «Сведения о врачебно-санитарной организации города Одессы», а в Ялті - «Врачебно-санитарная хроника» (1912) і «Санитарный бюллетень Ялты» (1913-1915) [7].

Зазначені лікарсько-санітарні хроніки та інші земські періодичні видання містили багатий матеріал про захворюваність і смертність населення України, про стан медичної допомоги, який $є$ цінним джерелом історії становлення та розвитку соціальної медицини.

Вагоме значення в поширенні медико-соціальних ідей в Україні мали «Научные санитарные новости» (1883-1884), «Труды Русского общества охранения народного здоровья» (1891-1913), журнали «Гигиена и санитарное дело», присвячений питанням громадської гігієни 
і санітарної статистики (1914-1917), «Общественно-санитарное обозрение» (1896-1897) і «Оздоровление России» (1915), які видавались у Петербурзі, а також «Журнал Общества русских врачей в память Н.И. Пирогова» (1895-1908) і його продовження «Общественный врач» (1909-1922), які видавались в Москві [7]. Більшість цих видань були багатопрофільними, але всі вони приділяли постійну увагу питанням здоров'я населення і організації медичної допомоги.

Серед інших журналів, що видавались в обох столицях імперії, для розвитку гігієнічної науки та санітарної просвіти, для зародження і поширення соціально-медичних ідей також мали значення наступні видання: «Будьте здорові»- популярно-медичний часопис, що виходив у Петербурзі у 1894-1900 pр. двічі на місяць; «Врач» - щотижневик, що його видавав В.А. Манасеїн, у якому містилося багато матеріалів із загальної гігієни та громадської медицини. Питання соціальної гігієни, епідеміології, судової медицини, медичної поліції висвітлювалися на сторінках таких часописів як «Вестник общественной гигиеньї, судебной и практической медицини», який виходив у Петербурзі в 1889-1917 рр. щомісячно та «Вестник судебной медицины и общественной гигиены», який виходив 4 рази на рік у 1882-1888 рр. у Петербурзі [17].

Окремі аспекти формування та поширення соціально-медичних ідей на теренах України знайшли висвітлення на сторінках таких видань: «Гигея»- часопис, який дуже короткий час видавав у Петербурзі у 1859 р. доктор медицини А. Ільїнський; «Друг здравия» - науковий та науково-популярний часопис, що видавався в Петербурзі впродовж 1833-1869 рр.; «Медицинский вестник» - щотижневик, який виходив у Петербурзі в 1861-1885 pp.; «Народное здравие» - популярний ілюстрований медичний часопис, який був розрахований на широке коло населення та містив популярні статті на медичні та гігієнічні теми і виходив щотижнево в 1899-1903 рр. у Петербурзі; «Общепонятная или популярная медицина», яку видавав у Петербурзі у 1860-1862 рр. доктор медицини М. Хан; «Русская медицина»щотижневий часопис, присвячений питанням гігієни та медицини, який виходив у Петербурзі в $1883-1895$ pp [7; 17].

Різноаспектні питання суспільної гігієни висвітлювалися на сторінках щомісячного науково-популярного журналу «Здоровье», який видався з 1874 по 1884 рр. Водночас із популярними статтями в щомісячнику з'являлися і наукові дослідження з проблем гігієни повітря, води, продуктів харчування тощо. Журнал висвітлював також необхідність розвитку наукової гігієни, організації гігієнічних лабораторій і підготовки на медичних факультетах лікарів-гігієністів, які б повністю присвячували себе цій галузі і показували на практиці, «що вони дійсно експерти, яких не може замінити в санітарних питаннях поліція» [3; 4].

Накопичений роками досвід профілактичної роботи земські лікарі висвітлювалися в таких періодичних виданнях як «Санитарное дело»- часопис, який раніше виходив під назвою «Военно-санитарное дело» (1881-1893) і був присвячений загальній, громадський та військовій гігієні і виходив у Петербурзі у 1891-1893 рр. щотижнево; «Современная медицина и гигиена» - часопис, присвячений гігієні та медицині, який виходив у Петербурзі в 1896-1910 pp., містив досить цікаві статті з гігієни і спочатку виходив щомісячно, а з 1907 р. двічі на місяць; «Спутник здоровья», який виходив у 1898-1905 рр. у Петербурзі щотижня i був розрахований на широке коло читачів [17].

У багатьох зазначених часописах брали участь українські вчені-гігієністи і лікарі, зокрема В.А. Субботін, А.І. Якобій, І.П. Скворцов, Ю.Ю. Гюбнер та ін.

Чільне місце в поширенні медико-соціальних ідей належало журналу «Харківський медичний журнал», перший номер якого вийшов 21 січня 1906 р. Створений Харківським медичним товариством, журнал проіснував до 1918 р. Для журналу були характерні такі особливості: по-перше, це був один із небагатьох провінційних журналів, який проіснував тривалий термін; по-друге, це був солідний журнал, у якому друкувалися матеріали не лише провінційних, а й столичних авторів; по-третє, це був журнал, в якому вагоме місце посідали питання медичної теорії, клініки і гігієни. Найбільша кількість праць в журналі 
друкувалася професора Мельникова-Разведенкова. Загалом, теоретичні праці в журналі займали $63 \%$, клінічні - 32,5\%, гігієнічні - 4,5\%. Журнал мав як науково-теоретичне, так і практичне спрямування [14, с. 59-60].

Слід підкреслити, що до початку XX ст. всі періодичні видання видавалися російською мовою. Це було пов'язано тим, що в Російській імперії видання наукової літератури українською мовою було категорично заборонено. Першим журналом, який вийшов українською мовою у 1913 р., був популярний часопис «Життя і знання», який містив статті на соціально-медичну тематику і видавався у Полтаві. У Галичині, яка на той час належала Австро-Угорській імперії, виходили також періодичні видання українською мовою. Спеціальної уваги заслуговує місячник «Здоровлє», який в 1912-1914 рр. видавало Українське лікарське товариство у Львові. Це був перший в Україні медичний журнал, який видавався українською мовою і багато сприяв опрацюванню та впровадженню в практику української медичної термінології. Його редагував відомий громадський діяч, доктор медицини Євген Озаркевич, а співпрацювали українські лікарі і вчені, в тому числі видатний учений, майбутній перший у світі міністр охорони здоров'я Іван Горбачевський [2, с.81].

Після революції 1917 р. більшість медичних часописів припинили своє існування. В умовах незалежної Української держави у 1918-1920 рр. в Києві виходили українською мовою «Вісник Міністерства народного здоров'я та опікування» і «Вісник Української Академії Наук». У 1918 р. $з$ ініціативи та за редакцією Свмена Лукасевича і за участю Київського медичного товариства почав виходити орган Всеукраїнської спілки лікарів «Українські медичні вісті». До 1920 р. вийшло 13 номерів цього журналу, закритого комуністичною владою [7, с.170].

У 1918 р. з ініціативи професорів М.Ф. Мельникова-Разведенкова, В.Я. Данилевського та інших українських учених як орган Харківського медичного товариства почав виходити двотижневий журнал «Врачебное дело», який потім став органом Народного комісаріату охорони здоров’я УРСР, був переведений до Києва і видається до цього часу. У 1919 р. почали виходити офіційні «Известия Народного комиссариата здравоохранения УССР» [2, с.82].

Дослідник у галузі історії медицини Василь Плющ вважає 1920-1929 pp. найблискучішим періодом розвитку української медичної преси [7]. Таке становище пов'язане з науковими досягненнями в різних галузях медичної науки, розвитком соціальної медицини у пореволюційні часи та процесом українізації.

На початку 20-х рр. XX ст. з'являється низка медичних часописів українською мовою. Одними 3 перших серед них були «Бюлетень Головної управи Українського Червоного Хреста» і «Київський медичний журнал». Продовжують виходити двомісячник під назвою «Українські медичні вісті». У 1927 р. у Харкові Головпросвіта, Укрнаука, НКОЗ, Харківський медичний інститут і Медична секція Харківського наукового товариства при ВУАН починають видавати «Український медичний архів», а у 1929 р. виходить «Дніпропетровський медичний журнал», який до того 31922 р. друкувався російською мовою. Деякий час видавалися «Киевский медицинский журнал» (1922, 1928-1930рр.), «Одесский медицинский журнал» (1927-1930рр.) і його попередник «Южный медицинский журнал, посвященный вопросам научной и практической медицини» (1926 р.) [2, с. 83].

Переважна більшість цих журналів були багатопрофільними і приділяли значну увагу питанням народного здоров'я та громадської медицини, продовжуючи і розвиваючи традиції прогресивної медичної преси дореволюційного періоду.

У 1922 р. у Харкові почав виходити спеціалізований місячник, присвячений питанням збереження i зміцнення здоров'я народу, проблемам соціальної медицини, під назвою «Профилактическая медицина», який з 1930 до 1937 р. виходив українською мовою. Цей журнал профілактичного спрямування став трибуною соціальних гігієністів. Ініціатором заснування журналу «Профілактична медицина» був учений-гігієніст С.А. Томілін. У 1926-1929 рр. як додаток до нього видавався орган наукової ради при Харківській облздоровінспектурі «Хроника здравоохранения» (3 1929 р. - «Хроніка здоровохорони»). На сторінках зазначеного журналу публікувалися статті С.А. Томіліна, присвячені різним напрямкам 
його діяльності - соціальній гігієні, демографії, організації охорони здоров'я [2, с. 84; 17 , с.157]. Зокрема, в його працях підкреслюється світоглядна роль соціальної гігієни у формуванні світогляду гігієніста.: «...глубокое изучение биологических законов психики личности, и психики коллектива - социальной жизни и её эволюционных тенденций должны сопутствовать социальному гигиенисту» [15, с. 32].

31925 до 1929 р. у Харкові і до 1941 р. у Києві виходив ілюстрований популярний місячник, а потім двотижневик для робітників і селян «Шлях до здоров'я» $\mathrm{i}$ додатки до нього «За здорове харчування», «За тверезість», «Здорова зміна». Проте всі ці журнали, крім «Врачебное дело», який з 1992 р. став двомовним під назвою «Лікарська справа», припинили своє існування в роки сталінського терору [2, с. 84].

Таким чином, історико-науковий аналіз періодичних медичних видань другої половини XIX - 20-х pp. XX ст. свідчить про їх багаточисельність та багатопрофільність. На сторінках журналів приділялася значна увага питанням народного здоров'я та громадської медицини, публікувалася велика кількість статей з різних питань суспільної гігієни, санітарної статистики, комунальної та шкільної гігієни, організації земської медицини, боротьби з соціальними та інфекційними хвороба, санітарно-освітньої роботи серед населення. Лікарсько-санітарні хроніки та інші земські періодичні видання містили багатий матеріал про захворюваність і смертність населення України, про стан медичної допомоги, який $є$ цінним джерелом історії становлення та розвитку соціальної медицини.

\section{ДЖЕРЕЛА ТА ЛІТЕРАТУРА}

1. Заблудовский П.Е. Медицина в России в период капитализма. Москва: Госмедиздат, 1956.150 с.

2. Коцур Н.І. Становлення і розвиток гігієнічної науки в Україні: шлях крізь епохи і соціальні потрясіння (друга половина XIX - 20-і pp. XX століття): монографія. КорсуньШевченківський, 2011. 726 с.

3. Коцур Н.І. Науково-практичні аспекти гігієни та епідеміології на сторінках періодичних видань (друга половина XIX - початок XX ст. // Переяславський літопис. Вип. 11. 2017. С. 91-99.

4. Левит М.М., Мультановский М.П. и др. Медицинская периодическая печать // Большая медицинская знциклопедия. 3-є изд. Москва: Советская знциклопедия, 1980. T. 14. 377-402 (1111-1187).

5. Осипов Е.А., Попов И.В., Куркин П.И. Русская земская медицина. Обзор развития земской медицины в России вообще и отдельно в Московской губернии с кратким статистическим отчетом страны и ея состояния. Москва: Тов. «Печатная С.П. Яковлева», $1899.340 \mathrm{c}$. 21.

6. О печатной гласности в медицине // Современная медицина. 1860. 21 янв. С. 17-

7. Плющ В. Медична преса в Україні // Матеріали до історії української медицини. Нью-Йорк, Мюнхен, 1995. Т. 1. С. 161-190.

8. Плющ В. Розвиток гігієни, санітарії та санітарної освіти // Нариси 3 історії української медичної науки та освіти. Кн. 2. XIX-XX ст. Мюнхен, 1983. С. 150.

9. Приказы по Медицинскому Департаменту // Вестн. судеб. медицины и обществен. гигиены. 1884. Т. 4. С. 4.

10. П’ятак О.А. Медичні журнали // Українська радянська енциклопедія (УРЕ). 2-е вид. Київ: Головна редакція УРЕ, 1981. Т 6. С. 431.

11. Робак І.Ю. Історичні умови організації та специфіка розвитку охорони здоров'я в Харкові (XVIII - початок XX ст): автореф. на здоб. наук. ступеня д-ра іст. наук: спец. 07.00.01 «Ітсорія України». Київ, 2009. 40 с.

12. Садівничий В.А. Соціокомунікативні параметри медичної преси підросійської України (середина XIX - початок XX ст. // Наукові записки Інституту журналістики. Том 56. 2014. Липень-вересень. С. 377-383. 
13. Садівничий В.А. «Відродження розпочинається із гласності...» (Медична преса Наддніпрянської України середини XIX - початку XX ст.): монографія. Дніпропетровськ: Середняк Т.К., 2015. 360 с.

14. 100-летие Харьковского научного медицинского общества. 1861-1961: сборник очерков и статей по истории деятельности /За ред. В.П. Новаченко. Київ: Здоров'я, 1965. $257 \mathrm{c}$.

15. Томилин С.А. Биологические елементы в социальной гигиене // Профилактическая медицина. 1922. № 2-3. С. 39-47.

16. Томилин С.А. Основные вопросы социальной гигиены // Профилактическая медицина. 1924. № 5-6. С. 66-78.

17. Хорош И.Д. Развитие санитарного дела в условиях земской медицины на Украине // Материалы к истории гигиены и санитарии на Украине / Под ред Д.Н. Калюжного и А.А. Грандо. Киев: Гос. мед. изд-во УССР, 1962. Т. 2. С. 27-34.

18. Ціборовський О.М. На варті здоров’я: монографія. Київ: Фант, 2010. 430 с.

19. Ціборовський О.М. Наукове і практичне значення досліджень 3 історії української медицини // Україна. Здоров’я нації. 2012. № 1 (21). С. 168-173.

\section{REFERENCES}

1. Zabludovskiy, P.E. (1956). Meditsina v Rossii v period kapitalizma [Medicine in Russia during the period of capitalism]. Moscow: Gosmedizdat [in Russian].

2. Kotsur, N.I. (2011). Stanovlennia i rozvytok hihiienichnoi nauky v Ukraini: shliakh kriz epokhy $i$ sotsialni potriasinnia (druha polovyna XIX - 20-i rr. XX stolittia): monohrafiia [Establishment and Development of Hygiene as a Science in Ukraine: History through Different Periods and Social Changes (second part of XIX century - 1920 s: monograph]. KorsunShevchenkivskyi [in Ukrainian].

3. Kotsur, N.I. (2017). Naukovo-praktychni aspekty ghighijeny ta epidemiologhiji na storinkakh periodychnykh vydanj (drugha polovyna XIX - pochatok XX st. [Scientific and organizational aspects of hygiene and epidemiology on the pages of periodicals (second half of the 19th - early 20th centuries)]. Perejaslavsjkyj litopys - Pereyaslavsky Chronicle, 11, 91-99 [in Ukrainian].

4. Levit, M.M. \& Multanovskiy, M.P. (1980). Meditsinskaya periodicheskaya pechat' [Medical periodicals]. Bol'shaya meditsinskaya zntsiklopediya - Big Medical Knowledgebase, 14, 377-402 (1111-1187) [in Russian].

5. Osipov, E.A., Popov, I.V. \& Kurkin, P.I. (1899). Russkaya zemskaya meditsina [Russian zemstvo medicine]. Obzor razvitiya zemskoy meditsiny $v$ Rossii voobshche $i$ otdel'no $v$ Moskovskoy gubernii s kratkim statisticheskim otchetom strany i eya sostoyaniya - Overview of the development of zemstvo medicine in Russia in general and separately in the Moscow province with a brief statistical report of the country and its condition. Moskva: Tov. «Pechatnaya S. P. Yakovleva» [in Russian].

6. (1860). O pechatnoy glasnosti $\mathrm{v}$ meditsine [About printed publicity in medicine]. Sovremennaya meditsina - Modern Medicine, 21 yanv., 17-21 [in Russian].

7. Pljushh, V. (1995). Medychna presa v Ukrajini [The medical press in Ukraine]. Materialy do istoriji ukrajinsjkoji medycyny - Materials to the history of Ukrainian medicine, 1 , 161-190 [in Ukrainian].

8. Pljushh, V. (1983). Rozvytok ghighijeny, sanitariji ta sanitarnoji osvity [Development of hygiene, sanitation and sanitary education]. Narysy $z$ istoriji ukrajinsjkoji medychnoji nauky ta osvity - Essays on the history of Ukrainian medical science and education, 2, 150-151 [in Ukrainian].

9. (1884). Prikazy po Meditsinskomu Departamentu [Orders for the Medical Department]. Vestn. sudeb. meditsiny i obshchestven. Gigieny - Vestn. destinies. medicine and public hygiene, 4 [in Ukrainian]. 
10. Pjatak, O.A. (1981). Medychni zhurnaly [Medical journals]. Ukrajinsjka radjansjka encyklopedija (URE) [Ukrainian Soviet Encyclopedia (URE)]. Kyiv: Gholovna redakcija URE [in Ukrainian].

11. Robak, I.Ju. (2009). Istorychni umovy orghanizaciji ta specyfika rozvytku okhorony zdorov'ja v Kharkovi (XVIII - pochatok XX st.):avtoref. na zdob. nauk. stupenja d-ra ist. nauk: spec. 07.00.01 «Istorija Ukrajiny» [Historical conditions of organization and specifics of health care development in Kharkiv (XVIII - beginning of XX century): abstract. on the image. Sciences. the degree of Dr. East. Sciences: Special. 07.00.01 «History of Ukraine»]. Kyiv [in Ukrainian].

12. Sadivnychyj, V.A. (2014). Sociokomunikatyvni parametry medychnoji presy pidrosijsjkoji Ukrajiny (seredyna XIX - pochatok XX st. [Socio-communicative parameters of medical press of sub-Russian Ukraine (middle of XIX - beginning of XX century)]. Naukovi zapysky Instytutu zhurnalistyky - Scientific notes of the Institute of Journalism, 56, 377-383 [in Ukrainian].

13. Sadivnychyj, V.A. (2015). «Vidrodzhennja rozpochynajetjsja iz ghlasnosti...» (Medychna presa Naddniprjansjkoji Ukrajiny seredyny XIX - pochatku XX st.): monoghrafija [ «Renaissance begins with publicity ...» (Medical Press of the Dnieper Ukraine in the MidNineteenth - Early Twentieth Centuries): monograph]. Dnipropetrovsjk: Serednjak [in Ukrainian].

14. Novachenko, V.P. (Ed.) (1965). 100-letie Khar'kovskogo nauchnogo meditsinskogo obshchestva. 1861-1961: sbornik ocherkov i statey po istorii deyatel'nosti [100th anniversary of the Kharkov Scientific Medical Society. 1861-1961: a collection of essays and articles on the history of activity]. Kyiv: Zdorov'ya [in Russian].

15. Tomylyn, S.A. (1922). Byolohycheskye elementy v sotsyalnoi hyhyene [Biological Elements in Social Hygiene]. Profylaktycheskaia medytsyna - Prophylactic Medicine, 2-3, 3947. [in Russian].

16. Tomilin, S.A. (1924). Osnovni pytannia sotsialnoi hihiieny [Main Principles of Social Hygiene]. Profylaktycheskaia medytsyna - Prophylaxis, 5-6, 16 [in Ukrainian].

17. Khorosh, I.D. (1962). Razvitie sanitarnogo dela v usloviyakh zemskoy meditsiny na Ukraine [The development of sanitary affairs in the conditions of zemstvo medicine in Ukraine]. Materialy $k$ istorii gigieny $i$ sanitarii na Ukraine - Materials on the history of hygiene and sanitation in Ukraine, 2, 27-34 [in Ukrainian].

18. Tsiborovskyi, O.M. (2010). Na varti zdorov'ia: istoriia stanovlennia sotsialnoi medytsyny $i$ okhorony hromadskoho zdorov'ia $v$ Ukraini: monohrafiia [Heathcare: History of Social Medicine and Healthcare Issues in Ukraine: monograph]. Kyiv: Fakt [in Ukrainian].

19. Ciborovsjkyj, O.M. (2012). Naukove i praktychne znachennja doslidzhenj z istoriji ukrajinsjkoji medycyny [Scientific and practical importance of research on the history of Ukrainian medicine]. Ukrajina. Zdorov'ja naciji - Ukraine. The nation's health, 1 (21), 168-173 [in Ukrainian].

Одержано 12.03.2019. 